\title{
Application in Pottery of the Residual Soils Associated to Marbles from the Estremoz Anticlinal Region
}

\author{
Ruben Martins $s^{1,2, a}$, Celso Gomes ${ }^{2, b}$, Luís Lopes ${ }^{1,3, c}$, Maria Arroz $^{4, d}$, \\ Dulce Santos ${ }^{4, d}$ Francisco Rosado ${ }^{5, \mathrm{e}}$, Ana Cunha ${ }^{1, \mathrm{f}}$ \\ ${ }^{1}$ Departamento de Geociências da Universidade de Évora, Portugal \\ ${ }^{2}$ Centro de Investigação GeoBioTec, FCT, Portugal \\ ${ }^{3}$ Centro de Geofísica de Évora (CGE), FCT, Portugal \\ ${ }^{4}$ CENCAL, Centro de Formação Profissional para a Indústria Cerâmica das Caldas da Rainha, \\ Portugal \\ ${ }^{5}$ Olaria Xico Tarefa, Portugal \\ arubenvm@uevora.pt, bcgomes@ua.pt, ${ }^{\mathrm{c}}$ lopes@uevora.pt, ${ }^{\mathrm{d}}$ analises@cencal.pt, \\ eolariaxt-redondo@sapo.pt, ${ }^{f}$ anamartacunha@gmail.com
}

Keywords: Terra Rossa, Mineralogy, Ceramic Properties, Pottery.

\begin{abstract}
Terra rossa is a residual soil that is derived from the chemical dissolution of carbonate rocks. This type of soil occurs in the region of the so-called Estremoz anticlinal, being the result of the weathering of extensive marble occurrences which are exploited for ornamental stone. The research work performed and disclosed in the present paper shows that terra rossa possesses appropriate compositional and technological properties for its use on ceramic applications, particularly for the local traditional pottery.

In potential marble quarry sites several thick soil horizons can be found, and whenever the soil is removed marble is shown up. As a rule, the removed soil is deposited around the quarry, and so far no use has been given to it.

Pottery has a long tradition in the Alentejo region, and Vila de Redondo and Aldeia de S. Pedro do Corval are known as emblematic centers of this activity. However, time has shown that the scarcity of high quality clay deposits has become an important issue. Therefore, potters are buying clay from other regions of Portugal, in particular in the area of Caldas da Rainha, located in the central west of the country and far from Alentejo, or even importing it from Spain.

The cooperative research work carried out in the Laboratories of DGUE, the Department of Geosciences at the University of Aveiro (DGUA) and CENCAL, and at the pottery owned by the artisan Mestre Xico Tarefa, in Vila de Redondo, has shown that terra rossa, due to its physicochemical, mineralogical and technological properties, can be used as a raw material in ceramic manufacturing, particularly in the traditional pottery produced both in Redondo and S. Pedro de Corval.
\end{abstract}

\section{Introduction}

The extractive industry of marble, particularly for ornamental stone, has high incidence in the counties of Estremoz, Borba and Vila Viçosa, where several hundreds of quarries exist in this region. Whenever quarrying works are initiated, the removal of both cover vegetation and soil is required, in order to allow marble exposure. The residual soil, called terra rossa, is normally deposited around the quarry cavity being formed, sometimes in a careless way, making difficult future extractive activity in nearby sites, as well as the environmental restoration of the quarry.

Physical, chemical, mineralogical and technological studies were planned and carried out on several soil samples collected in different deposits of terra rossa, looking at its potential use as a raw material for ceramic manufacturing, particularly in pottery [1]. 